\title{
EVALUATION OF LOCAL MACHINE PERFORMANCE FOR THRESHING BEAN
}

\section{A. K. ZAALOUK}

\section{ABSTRACT}

The objective of this paper is to study the feasibility of using locally made threshing machine for dry bean( Giaz 6 seed) and selecting the optimum conditions for operation. Threshing drum speeds tested were 11.72, 13.18 and $15.38 \mathrm{~m} / \mathrm{sec}$., feed rates 10,15 and $20 \mathrm{~kg} / \mathrm{min}$ and seed was used at moisture contents of 13.56, 11.53 and $9.20 \%$. The obtained results show that, the local threshing machine can be successfully used for threshing bean under the following conditions: seed moisture content $9.20 \%$ drum speed $15.38 \mathrm{~m} / \mathrm{sec}$ and feed rate $20 \mathrm{~kg} / \mathrm{min}$, resulting in seed damage of $2.17 \%$ and un-threshed seed of $1.48 \%$ ,threshing efficiency of $98.52 \%$, consumed power $14.70 \mathrm{~kW}$ and criterion cost of 143.20 L.E/ton including operation and losses.

\section{INTRODUCTION}

(Phaseolus Vulgaris, L. ) bean is a favorite commodity for export and local consumption. The successful production and good marketability of this crop depend on both quantity and quality of the crop . To increase seed production with good quality feasibility of threshing machine must be for dry bean seed threshing and selecting the optimum operating conditions.

Up till now, the manual threshing of bean crop is still the common practice followed by the majority of the farmers in Egypt .

Sharma and Devnanl (1980) dealt with the threshing of soybean and cowpea. Threshing efficiency increased with the increase of cylinder speed but decreased with the increase of feeding rate and concave clearance. Energy consumption was directly proportional to cylinder speed, feed rate and remained constant at selected concave clearance. At higher speeds, the visible grain damage was 5\% and the germination percentage was low.

Lect., Agr. Eng. Dep., Fac. of Agr. Al-Azhar Univ. 
Huynh et al.(1982) reported that the seed separation from the stalks and passage of seed through the concave gate is a function of some variables such as crop feed rate, threshing speed, concave length and cylinder diameter and concave clearance.

These variables are also related to the threshing losses and seed separation efficiency.

Anwar and Gopta(1990) reported that the percentage of grain damage increased with on increase in cylinder speed for all feed rates and concave combinations. The mean grain damage decreased with increasing concave clearance and feed rate. The percentage of total machine losses increased with cylinder speeds from 480 to $530 \mathrm{rpm}$. Abo El-Khair (1991) concluded that the un-threshed seed losses decreased with an increase in cylinder speed and with a decrease in cylinderconcave clearance for two levels of moisture. In addition, the unthreshed-seed losses increased with an increase in seed moisture level of seed at all parameters of both cylinder speed and cylinder-concave clearance.

Ajayi(1991) indicated that the material capacity of a thresher is influenced by speed of the threshing beater drum, the feed rate and the moisture contents of material.At lower speeds of 300 and $500 \mathrm{rpm}$ of beater drum, the material at $13.3 \%$ moisture gave slight decrease in capacity as the speed increased to $500 \mathrm{rpm}$.

The main objectives of this paper is to study the feasibility of using local threshing machine for threshing dry bean seed and select the optimum conditions of threshing : drum speed, feed rate and moisture content .

\section{MATERIALS AND METHODS}

Field experiments were carried out for threshing bean crop ( Gize 6 variety ) in a private farm in EL- Ibrahimia village, Dosuq, Kafr Elsheikh Governorate ( الأبر اهيمية _ دسوق - كفر الثيخ ) during season 2008 . All experiments were conducted using a local threshing machine.

The specifications of these machines are shown as follows:

Threshing machine specifications:

Made: Local 
Threshing drum:

Type: Spike tooth

Drum diameter: $70 \mathrm{~cm}$.

Drum length $\quad: 120 \mathrm{~cm}$.

Knives: 44 knives $(30 \mathrm{~cm}$. long $-5 \mathrm{~cm}$. width- $0.7 \mathrm{~cm}$. thick)

Concave:

Type : Perforated sheet of $0.5 \mathrm{~cm}$. thick .

Concave holes (No./ $100 \mathrm{~cm}^{2}$ ) 9

Concave hole diameter $2.2 \mathrm{~cm}$. Used for Faba bean

The power was transmitted from tractor ( Nasr, four-stroke diesel engine $44.10 \mathrm{~kW}(60 \mathrm{Hp})$ to thresher machine by a pulley and belt.

The threshing machine performance was studied under the following condition:

-Three different of feeding rates of 10,15 and $20 \mathrm{~kg} / \mathrm{min}$.

- Three different of peripheral drum speeds of $11.72,13.18$ and 15.38 $\mathrm{m} / \mathrm{sec}$.

-Three different seed moisture contents of 13.56, 11.53 and $9.20 \%$ (d.b) at the optimum maturity of dry bean plant .The physical properties of bean seed crop used in all experimental tests are shown in table (1).

Table (1) some physical properties of the dry bean plant.

\begin{tabular}{|l|l|}
\hline Characteristics & Average value \\
\hline Stem length ,(mm) & 492 \\
\hline Stem diameter,$(\mathrm{mm})$ & 8.66 \\
\hline Number of branches/ plant, & 14 \\
\hline Number of pods/ plant, & 35.8 \\
\hline Pod dim. ( L x W x T ), mm & $118 \times 8.4 \times 7.35$ \\
\hline Seed dim. ( Lx W x T ), mm & $15.27 \times 7.46 \times 6.29$ \\
\hline Number of seeds /pod . & 5 \\
\hline
\end{tabular}

Measurements:

1- Productivity $(\mathrm{kg} / \mathrm{h})$ : machine productivity was calculated as follows:

$$
\mathrm{P}=\mathrm{w} / \mathrm{t} \quad(\mathrm{kg} / \mathrm{h})
$$

Where:

$$
\mathrm{P}=\text { Machine productivity, }
$$$$
\mathrm{kg} / \mathrm{h}
$$ 


$$
\begin{aligned}
& \mathrm{w}=\text { The mass of total yield, } \quad \mathrm{kg} \\
& \mathrm{t}=\text { The time consumed in threshing operation, }
\end{aligned}
$$

2 - Seed losses percentage ( $\%$ ): seed losses were calculated as follows:

- Un-threshed seeds $=\mathrm{U}_{\mathrm{ns}} / \mathrm{T}_{\mathrm{s}} \times 100$

Where:

$$
\mathrm{U}_{\mathrm{ns}}=\text { Mass of un-threshed seed, } \mathrm{kg}
$$$$
\mathrm{T}_{\mathrm{s}}=\text { Total mass of seeds, } \mathrm{kg}
$$

- Seed damage $=\mathrm{D}_{\mathrm{s}} / \mathrm{T}_{\mathrm{s}} \times 100$

Where:

$$
\text { Ds }=\text { Mass of damaged seeds } \mathrm{kg}
$$

- Total losses $=\mathrm{U}_{\mathrm{ns}}+\mathrm{D}_{\mathrm{s}}$

3- Threshing and cleaning efficiency:

The threshing efficiency was calculated according to the following formula:

- Threshing efficiency $=\mathrm{S}_{\mathrm{t}} / \mathrm{T}_{\mathrm{s}} \mathrm{x} 100$

Where:

$\mathrm{S}_{\mathrm{t}}=$ Mass threshing seeds. $\mathrm{Kg}$

$\mathrm{S}_{\mathrm{t}}=$ Mass of total seeds input per unit time - mass of un-threshed seeds pre time.

- Seed output mass was measured using a spring balance of $50 \mathrm{~kg}$ limit and $0.5 \mathrm{~kg}$ accuracy and time elapsed was measured using a stop watch for $60 \mathrm{~min}$. (0.1 sec. accuracy ).

- Threshing drum speeds (rpm): was measured using tachometer. Peripheral speed was calculated as follows:

$$
\mathrm{V}=\pi \mathrm{ND} / 60
$$

Where:

$$
\mathrm{V}=\text { Rotational speed }(\mathrm{rpm}) \quad \mathrm{D}=\text { Threshing drum diameter, } \mathrm{m}
$$

- The seed moisture content was determined on dry basis using the oven method at $105^{\circ} \mathrm{C}$ for 24 hours.

- The cracked and damaged seeds were determined by hand collecting and weighing from one $\mathrm{kg}$ of output seeds.

4- Power requirements:

To estimate the engine power during threshing operation, the decrease in fuel level was accurately measured immediately after each treatment. 
The following formula was used to estimate the corresponding used engine power (EP) according to Hunt (1983).

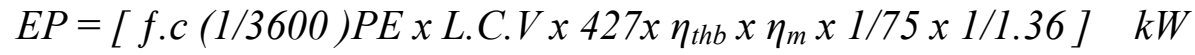

Where :

$f . \mathrm{c}=$ The fuel consumption, $(\mathrm{L} / \mathrm{h})$

$\mathrm{PE}=$ The density of fuel, $(\mathrm{kg} / \mathrm{L})(0.823 \mathrm{~kg} / \mathrm{L})$

L.C.V = The lower calorific value of fuel, $(11000 \mathrm{k} . \mathrm{cal} / \mathrm{kg})$

$\mathrm{H}_{\text {thb }}=$ Thermal efficiency of the engine, ( $35 \%$ for Diesel $)$

$4277=$ Thermo- mechanical equivalent, $(\mathrm{Kg} \cdot \mathrm{m} / \mathrm{k} \cdot \mathrm{cal})$

$\eta_{\mathrm{m}}=$ Mechanical efficiency of the engine, ( $80 \%$ for Diesel )

5- Threshing cost : was calculated according to the equation given by( Awady,1978) which had the following form :

$C=\mathrm{p} / \mathrm{h}\{(1 / \mathrm{a}+\mathrm{i} / 2+\mathrm{t}+\mathrm{r})+(0.9$ W .S.F $)+\mathrm{m} / 144\}$

Where :

$\mathrm{C}=$ Hourly cost, L.E/h

$\mathrm{h}=$ Yearly working hours, $\mathrm{h} /$ year

$\mathrm{p}=$ Price of machine, L.E

machine, year

$\mathrm{i}=$ Interest rate/year.

$\mathrm{a}=$ Life expectancy of the

$\mathrm{t}=$ Taxes and overheads rate,

$\mathrm{F}=$ Fuel price, L.E / L.

$\mathrm{m}=$ Monthly average wage, $\mathrm{L} . \mathrm{E}$

$\mathrm{r}=$ Repairs and maintenance ratio.

lubrications.

$\mathrm{W}=$ Engine power, $\mathrm{hp} . \quad \mathrm{S}=$ Specific fuel consumption, $\mathrm{L} / \mathrm{hp} . \mathrm{h}$.

$144=$ Reasonable estimation of monthly working hours .

The criterion function cost $\left(\mathrm{C}_{\mathrm{f}}\right)$ was calculated to determine the optimum operating parameter for the used machine. This function can be calculated as the sum of machine operation cost ( $U_{c}, L . E /$ ton ) plus the losses cost ( $\mathrm{L}_{\mathrm{c}}$, L.E/ton) (Awady et.al., 1982 and Helmy, 1988 ).

$$
\mathrm{C}_{\mathrm{f}}=\mathrm{U}_{\mathrm{c}}+\mathrm{L}_{\mathrm{c}}
$$

Where:

$\mathrm{L}_{\mathrm{c}}=10^{-2} \mathrm{C}_{\mathrm{pw}} \times\left(\mathrm{U}_{\text {nther }} \mathrm{S}+0.33 \mathrm{~T}_{\mathrm{SD}}\right)$

$\mathrm{C}_{\mathrm{pw}}=$ Current price of one ton of bean seeds ( 5000 L.E/ton )

$\mathrm{U}_{\text {nther.S }}=\mathrm{Un}$-threshed seed, \%

$\mathrm{T}_{\mathrm{SD}}=$ Total seed damage, $\%$.

* Current price of one ton of broken bean seeds $=0.33 \mathrm{C}_{\mathrm{pw}}$. 


\section{RESULTS AND DISCUSSION \\ Effect of threshing parameters on un-threshed seed}

Fig. (1) indicated that, increasing the drum speed from 11.72 to 15.38 $\mathrm{m} / \mathrm{s}$ decreased the un-threshed seed from 1.58 to 1.24 , from 1.77 to 1.37 and from 1.87 to $1.48 \%$ at different feed rates of 10,15 and $20 \mathrm{~kg} / \mathrm{min}$ respectively and constant seed moisture content of $9.20 \%$, while increasing the moisture content to $13.56 \%$ increased the un-threshed seed from 2.68 to 3.20 ,from 2.60 to 3.11 and from 2.55 to $3.00 \%$ under the same pervious conditions .

It is clear from data and figure that, increasing the drum speed decreased the un-threshed seed. In addition, increasing the feed rate and the seed moisture content increased the un-threshed seed.

Effect of threshing parameters on seed damage:-

Fig. ( 2 ) increasing the drum speed from 11.72 to $15.38 \mathrm{~m} / \mathrm{s}$ increased the seed damage from 2.40 to 2.90 , from 1.95 to 2.51 and from 1.89 to $2.17 \%$ at different feed rates of 10,15 and $20 \mathrm{~kg} / \mathrm{min}$ respectively and constant seed moisture content of $9.20 \%$, while increasing the seed moisture content to $13.56 \%$ increased the seed damage from 1.92 to 2.43 , from 1.67 to 2.10 and from 1.51 to $1.90 \%$ under the same pervious conditions. It is clear from data and figure that increasing the drum speed increased the seed damage. In addition, increasing the feed rate and the seed moisture content decreased the seed damage.

-Effect of threshing parameters on threshing efficiency:

From fig. (3) it is clear that increasing the drum speed from 11.72 to $15.38 \mathrm{~m} / \mathrm{s}$ increased the threshing efficiency from 98.42 to 98.76 , from 98.23 to 98.63 and from 98.13 to $98.52 \%$ at feeding rates 10,15 and 20 $\mathrm{kg} / \mathrm{min}$ respectively and constant seed moisture content $9.20 \%$, while increasing the seed moisture content to $13.56 \%$ increased the threshing efficiency from 97.32 to 97.45 , from 97.00 to 97.25 and from 96.80 to $97.00 \%$ under the same pervious conditions.

In all cases, threshing efficiency increased by increasing drum speed and decreased by increasing seed moisture content and feed rate.

- Effect of threshing parameters on power :

Fig. (4 ) shown that increasing the drum speed from 11.72 to $15.38 \mathrm{~m} / \mathrm{s}$ increased the power from 12.29 to 13.99 , from 12.61 to 14.38 and from 
12.78 to $14.70 \mathrm{~kW}$ at different feed rates of 10,15 and $20 \mathrm{~kg} / \mathrm{min}$ respectively and constant seed moisture content of $9.20 \%$, while increasing the seed moisture content to $13.56 \%$ increased the power from 12.67 to 14.35 , from 12.92 to 14.79 and from 13.26 to $15.26 \mathrm{~kW}$ under the same pervious conditions.

- $\quad$ Effect of threshing parameters on the operating and losses cost:

Criterion cost is considered the best method to determine the optimum conditions of operation. The costs included the operating cost and losses cost. The operating cost affected directly by the productivity. From data, it is clear that increasing drum speed from 11.72 to $15.38 \mathrm{~m} / \mathrm{s}$ decreased un-threshed seed cost from 79 to 62 , from 88.5 to 68.5 and from 93.5 to $74 \mathrm{~L} . \mathrm{E} / \mathrm{ton}$ at feeding rates 10,15 , and $20 \mathrm{~kg} / \mathrm{min}$ respectively and constant seed moisture content $9.20 \%$, while increasing the seed moisture content to $13.56 \%$ decreased un-threshed seed cost from 134 to 127 , from 150 to 137.5 and from 160 to $150 \mathrm{~L}$.E/ton under the same pervious conditions. The operating cost decreased from 67 to $33.49 \mathrm{~L} . \mathrm{E} /$ ton at feeding rates from 10 to $20 \mathrm{~kg} / \mathrm{min}$ and consequently criterion cost decreased from 158.17 to 143.29 L.E/ton recording the lowest value of cost which was achieved at seed moisture content of 9.20 $\%$ feed rate $20 \mathrm{~kg} / \mathrm{min}$ and drum speed $15.38 \mathrm{~m} / \mathrm{s}$.

From fig. ( 5 ) it is clear that increasing the feeding rates 10 to $20 \mathrm{~kg} / \mathrm{min}$ criterion cost decreased from 185 to158.17, from 176.21 to 150.32 and from 176.85 to 143.29 L.E/ton at drum speed $11.72,13.18$ and $15.38 \mathrm{~m} / \mathrm{s}$ respectively and constant seed moisture content $9.20 \%$, while increasing the seed moisture content to $13.56 \%$ criterion cost decreased from 232.68 to 218 , from 233.3 to 217.86 and from 234.50 to $214.84 \mathrm{~L}$.E/ton under the same pervious conditions. 

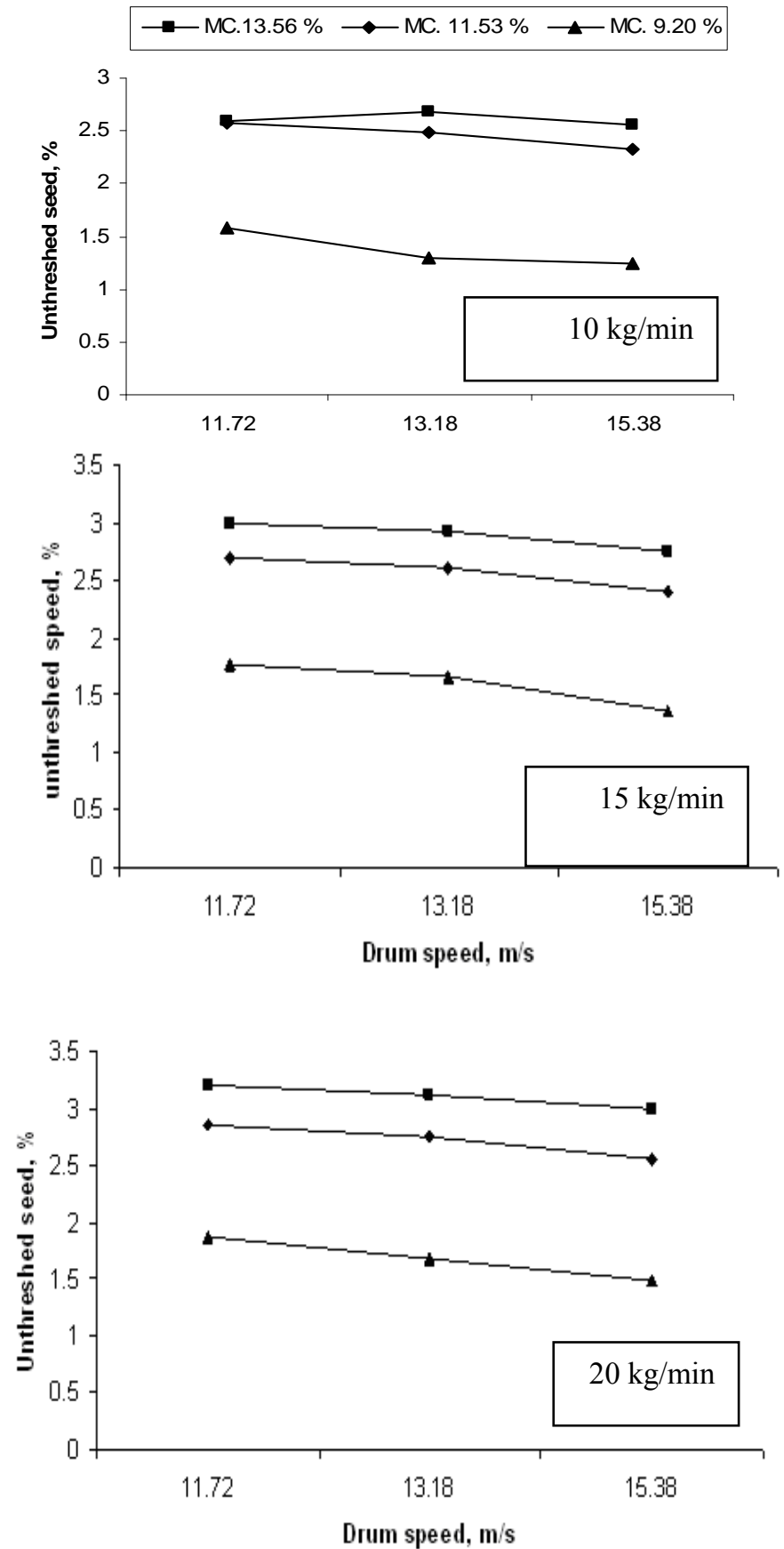

Fig. (1) Effect of drum speed and moisture content on un-threshed seed at different feed rate. 

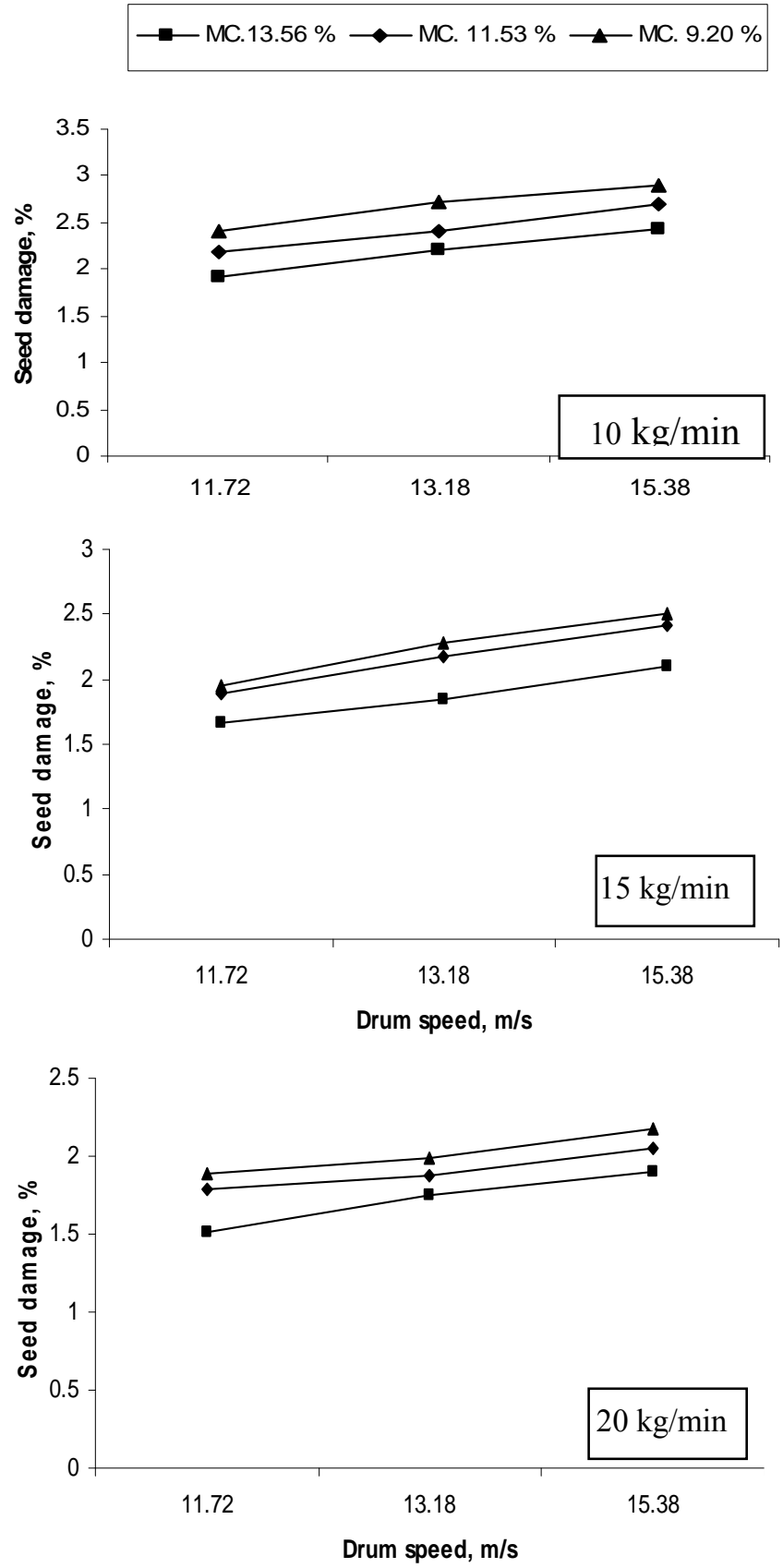

Fig. (2 ) Effect of drum speed and moisture content on seed damage at different feed rates. 

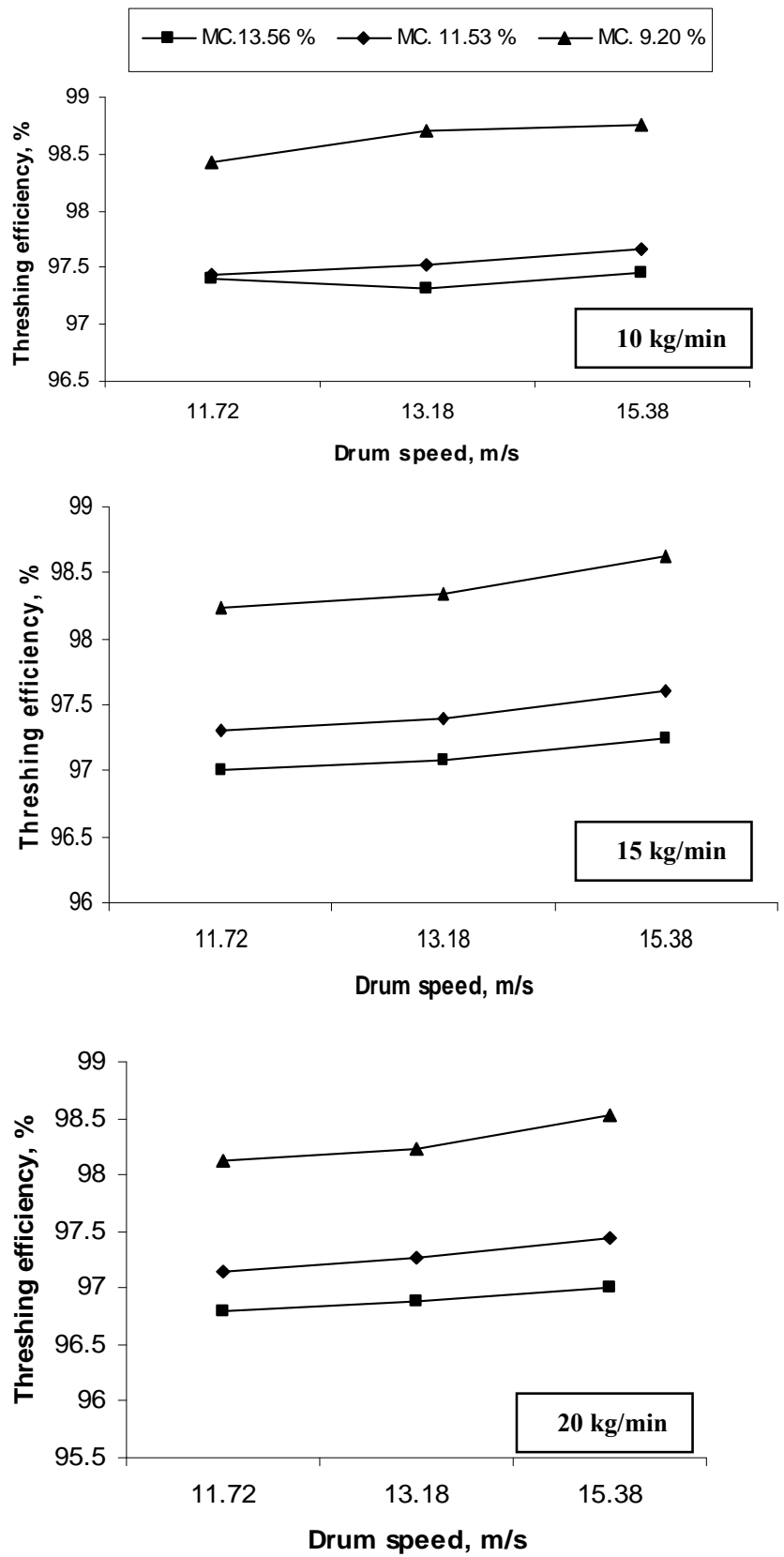

Fig (3) Effect of drum speed and moisture content on threshing efficiency at different feed rates. 

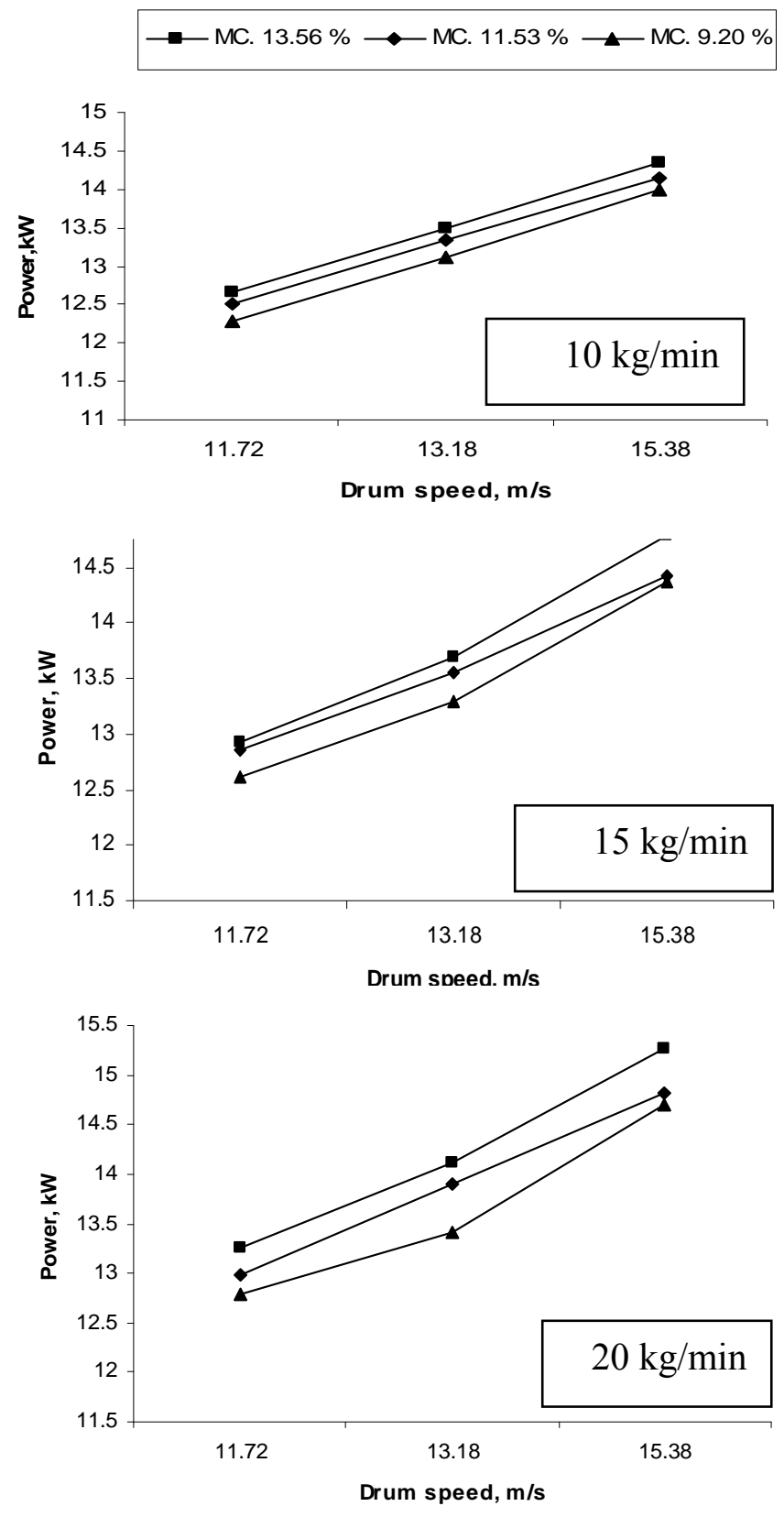

Fig. (4) Effect of drum speed and moisture content on power at different feed rates . 

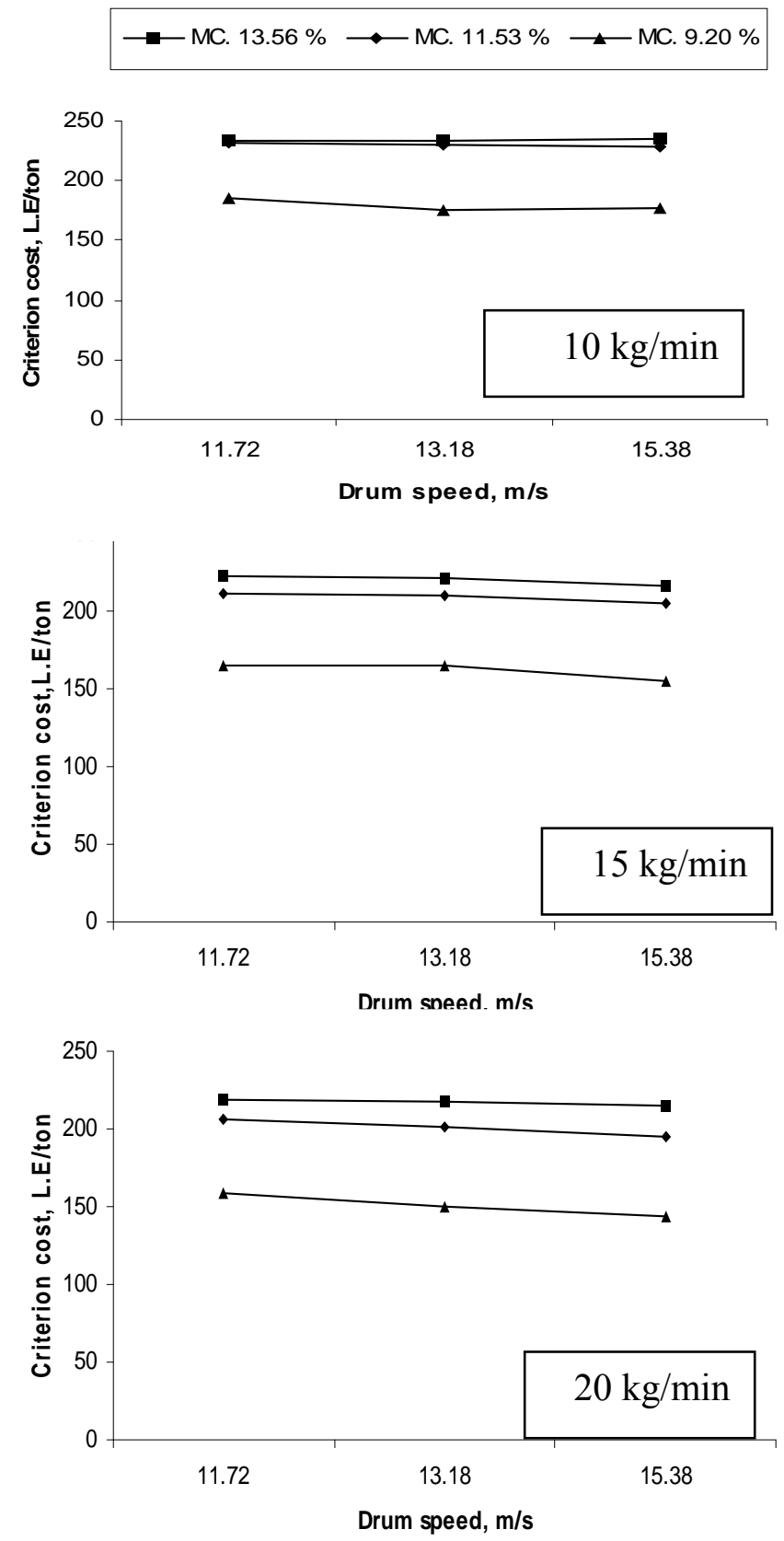

Fig. (5 ) Ettect ot drum speed and moisture content on criterion cost at different feed rates. 


\section{CONCLUSIONS}

The results showed the following :

1- Increasing drum speed from 11.72 to $15.38 \mathrm{~m} / \mathrm{s}$ decreased unthreshed seed, while increasing seed damage.

2- Increasing feed rate from 10 to $20 \mathrm{~kg} / \mathrm{min}$ increased un-threshed seed , while decreasing seed damage

3- Increasing seed moisture content from 9.20 to $13.56 \%$ increased unthreshed seed, while decreasing seed damage .

4- The optimum condition for operating the threshing machine were at seed moisture content of $9.20 \%$, drum speed of $15.38 \mathrm{~m} / \mathrm{s}$ and feed rate $20 \mathrm{~kg} / \mathrm{min}$. resulting in seed damage of $2.17 \%$, un-threshed seed of 1.48 $\%$,threshing efficiency of $98.52 \%$, consumed power $14.70 \mathrm{~kW}$ and criterion cost of 143.29 L.E/ton.

\section{REFERENCES}

Abo EL-kheir, M. M. (1991). Effect of some factor on threshing performance of soybean, Misr J .Ag. Eng., 8 (3):172-181.

Anwar, M.T. and G. P. Gopta. (1990). Performance evaluation of chick pea thresher in Pakistan AMA 21 (5) : 23-28Ajayi, O. A. (1991).Design of threshing for locust bean ,AMA 22 (3) : 21-24.

Awady, M. N., Ghoniem, E. Y., and Hashish, A. I. (1982). A critical comparison between wheat combine-harvesters under Egyptian condition, Res. Bul. No. 1920, Fac. of Ag. Ain Shams Univ. : 13p.

Awady, M. N. (1987). Tractor and farm machinery . Textbook, Ag. Eng. Dept. Fac. Of Ag. Ain Shams Univ. : 164-167.

Helmy, M. A. ( 1988 ). Threshing parameter affecting the performance of local and foreign wheat threshing machine. Misr J.Ag. Eng.,5 ( 4 ): 329-343.

Hunt, D. (1983). Farm power and machinery management. $8^{\text {th }}$ Ed. Iowa state Univ., Press Ames USA: 364-368.

Hunynh, V. M; Powell, T. and Siddal, J. N. (1982). Threshing and separating process-A mathematical model. Trans. ASAE, 25 (1) : 6273. 
Sharma, K.D. and R.SA.Devananl (1980).Threshing studies on soybean and cowpea. AMA 33 (2) 65-68.

\section{الملخص العربي}

\section{تقييم أداء آلة محلية في دراس محصول القاصوليا

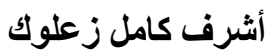

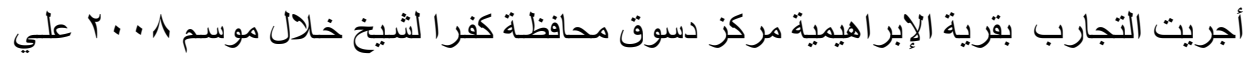

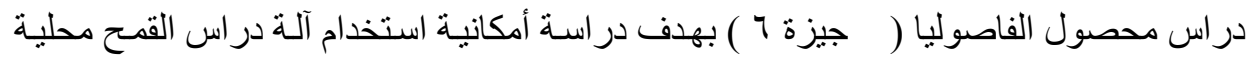

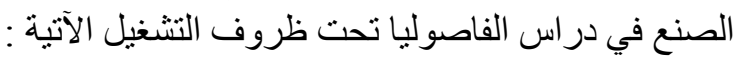

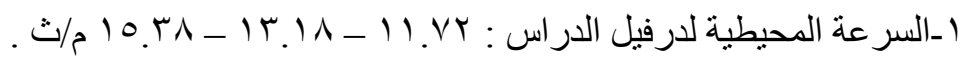

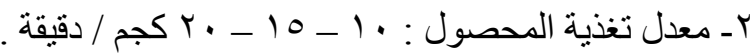
rـ المحتوى الرطوبي : • ·.

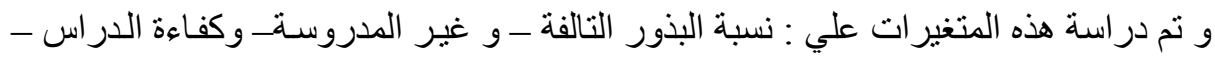

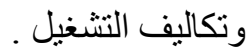

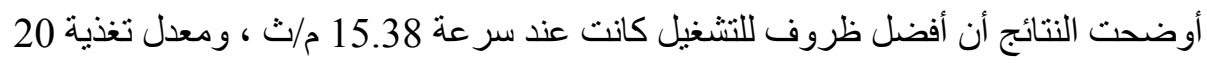

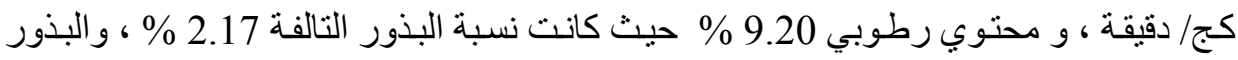

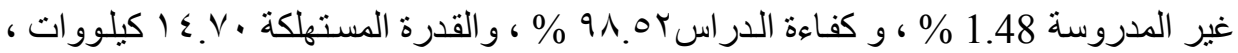

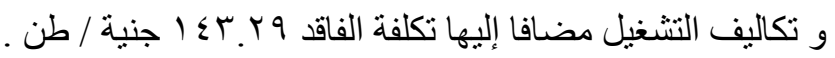

مدرس - قسم الهندسة الزر اعية - كلية الزر اعة - جامعة الأز هر بالقاهرة 